\title{
AKUNTABILITAS DAN TRANSPARASI DALAM PELAYANAN PUBLIK (Studi pada Dinas Kependudukan dan Catatan Sipil Kabupaten Mesuji)
}

\author{
Yuditya Wardhana, S.A.N.,M.Si \\ yuditya5290@gmail.com \\ STISIPOL DHARMA WACANA Metro Lampung
}

\begin{abstract}
ABSTRAK
Penelitian ini bertujuan untuk mengetahui bagaimana Akuntabilitas dan Transparasi dalam Pelayanan Publik pada Dinas Kependudukan dan Catatan Sipil Kabupaten Mesuji. Metode penelitian yang digunakan dalam penelitian ini yaitu kualitatif dengan data diambil dengan wawancara dan observasi, sedangkan analisis data yang digunakan adalah analisis kualitatif deskriptif. Hasil penelitian menunjukkan bahwa Penerapan prinsip akuntabilitas dalam pelayanan KTP, AKTA, dan KK di Dinas Kependudukan dan Catatan Sipil Kabupaten Mesuji Kecamatan Raya sudah berjalan dengan baik. Hal tersebut tercermin dari jawaban dalam wawancara dan observasi penelitian baik kepada Dinas Kependudukan dan Catatan Sipil Kabupaten Mesuji atau masyarakat yang mengatakan baik terhadap beberapa indikator yang terkandung di dalam prinsip akuntabilitas. Transparansi dalam pelayanan pengurusan KTP, AKTA, dan KK di Dinas Kependudukan dan Catatan Sipil Kabupaten Mesuji terbukti terlaksana dengan baik. Hal tersebut tercermin dari jawaban dalam wawancara penelitian baik kepada Dinas Kependudukan dan Catatan Sipil Kabupaten Mesuji atau masyarakat tentang keterbukaan dalam Pelayanan kepengurusan KTP, AKTA, dan KK.
\end{abstract}

Kata Kunci: Akuntabilitas, Transparansi Pelayanan Publik

\section{PENDAHULUAN}

Semenjak digulirkannya gerakan reformasi politik tahun 1998 yang diikuti dengan runtuhnya pemerintahan orde baru, kebutuhan untuk adanya suatu pembaruan atau reformasi dalam tubuh birokrasi yang memenuhi prinsip-prinsip akuntabilitas dan transparansi sangat mendesak dilakukan. Pembaruan atau reformasi birokrasi dipandang merupakan langkah strategis menuju penyelenggaraan kepemerintahan yang demokratis dan efisien (good governance). Transparansi publik merupakan indikator yang sangat penting dalam pembangunan tata pemerintahan yang baik. Kebutuhan akan praktek pelayanan publik yang transparan dalam good governance di tingkat pemerintahan daerah saat ini menjadi suatu hal yang tidak terelakkan. Mengingat bahwa sebuah pemerintahan yang baik dan demokratis mensyaratkan institusi kelembagaan pemerintah yang transparan dan efektif untuk melayani kebutuhan kliennya-publik. Praktek good governance menuntut pemerintah untuk menjamin keterbukaan akses informasi kepada stakeholders terhadap kebijakan publik dari pemerintah baik dalam konteks proses kebijakan publik, alokasi anggaran yang disalurkan untuk implementasi kebijakan maupun evaluasi 
dan kontrol terhadap praktek kebijakan yang dilakukan.

Dinas Kependudukan dan Catatan Sipil Kabupaten Mesuji juga tidak pernah menginformasikan suatu bentuk laporan pertanggungjawaban atas kinerja mereka kepada masyarakat. Sehingga masyarakat tidak mengetahui apa-apa saja yang menjadi program kerja Dinas Kependudukan dan Catatan Sipil Kabupaten Mesuji dalam menjalankan tugas dan fungsinya. Transparansi dalam hal pelaksanaan kegiatan dan pemberian informasi juga sangat terbatas. Hal ini tentu saja membuat masyarakat kurang simpati dan kurang percaya atas kinerja para pegawai Dinas Kependudukan dan Catatan Sipil Kabupaten Mesuji.

Atas dasar itulah penulis tertarik untuk mengambil judul studi tentang Akuntabilitas dan Transparansi dalam Pelayanan Publik (Studi Pada Dinas Kependudukan dan Catatan Sipil Kabupaten Mesuji).

\section{METODE}

Tipe penelitian yang digunakan adalah tipe Kualitatif deskriptif yang dimaksudkan untuk memberikan gambaran secara jelas mengenai masalah-masalah yang diteliti, menginterpretasikan serta menjelaskan data secara sistematis. Dasar penelitian ini adalah survey, yaitu pembagian kuesioner kepada responden yang berisi pertanyaan-pertanyaan mengenai hal yang berhubungan dengan penelitian yaitu mengenai pembuatan Kartu Tanda Pendudukan (KTP), Kartu Keluarga
(KK), dan Akta. Metode yang digunakan dalam penelitian ini adalah metode:

1) Wawancara

Teknik wawancara secara umum seringkali digunakan oleh peneliti yang menggunakan metode penelitian kualitatif (qualitatif approach). Interview dapat digunakan untuk mengumpulkan informasi yang tidak mungkin diperoleh lewat observasi. Teknik interview ini paling tepat digunakan pada saat peneliti ingin mengetahui secara lebih objektif dan terlibat secara langsung mengenai bagaimana pelaksanaan mekanisme pelaksanaan pemerintah yang akan ditampilkan oleh sumber tatkala melakukan sesuatu aksi tertentu dalam kondisi tertentu, serta faktorfaktor yang menjadi penghambat dan penunjungnya.

2) Dokumentasi

Adalah suatu cara untuk memperoleh data melalui peninggalan tertulis seperti arsip-arsip dan termasuk juga buku-buku tentang pendapat, teori, dalil atau hukum-hukum dan lain-lain yang berhubungan dengan masalah penelitian.

3) Observasi

Yaitu data yang dibutuhkan diperoleh dengan melakukan pengamatan langsung terhadap fenomena yang relevan dengan fokus penelitian di penelitian. Penekanan observasi lebih pada upaya mengungkap maknamakna yang terkandung dari berbagai aktivitas terarah tujuan. Tindakan saat menghadapi rintangan dan aktivitas 
tujuan dari para pegawai Dinas Kependudukan dan Catatan Sipil Kabupaten Mesuji dalam memainkan perannya disetiap tahapan proses kegiatan pemerintah. Dalam Penelitian ini yang di observasi peneliti adalah:

a. Akuntabilitas kinerja

b. Akuntabilitas produk pelayanan publik

c. Penyelenggaraan pelayanan publik

Dan hasil observasi tersebut dimasukkan dan dicatat dalam buku catatan yang selanjutnya dilakukan pemilahan sesuai kategori yang ada dalam fokus penelitian.

\section{ANALISIS HASIL DAN PEMBAHASAN}

\subsection{Transparansi dalam Pelayanan} Publik Dinas Kependudukan dan Catatan Sipil Kabupaten Mesuji

Transparansi merupakan konsep yang pertama dari keenam konsep kualitas pelayanan, transparansi menjadi salah satu faktor dan ukuran penting dari good governance. Pelayanan akan terlihat baik dan buruk dinilai dari adanya sebuah transparansi di dalam pemerintahannya. Transparansi menjadikan peran yang sangat penting bagi sebuah pelayanan, terlihat dari sukses dan tidaknya pelayanan pembuatan KTP, Akta dan KK kepada masyrakat, khusunya masyarakat yang ada di Kabupaten Mesuji.

Transparan dapat mewujudkan kualitas pelayanan akan kebutuhan para masyarakat, khususnya para aparatur dalam pelayanan KTP, Akta dan KK dalam meningkatkan kinerja pelayanan yang baik terhadap masyarakat. Pelayanan yang diberikan oleh aparatur di Dinas Kependudukan dan Catatan Sipil Kabupaten Mesuji kepada masyarakat memiliki tujuan agar masyarakat mendapatkan dan memenuhi serta memiliki data kependudukannya secara legal dan tercatat di Dinas Kependudukan Catatan Sipil.

Dengan adanya transparansi akan memudahkan masyarakat dalam membuat KTP, Akta dan KK dengan mudah, cepat dan tanpa biaya yang dikeluarkan sesuai dengan UndangUndang 23 Tahun 2014 yang menyatakan bebas biaya tanpa pungutan Rp.0,-. Sehingga akan menimbulkan peningkatan kualitas pelayanan dalam rangka mewujudkan harapan masyarakat akan kebutuhan data kependudukan, untuk mengukur konsep transparansi ini, peneliti mendasarkan pada beberapa konsep yang dijadikan item-item pada pertanyaan untuk informan dalam penelitian.

\subsection{Transparansi Proses}

Penyelenggaraan Pelayanan Pembuatan KTP, Akta dan KK.

Keterbukaan proses penyelenggaraan pelayanan publik dalam memberikan pelayanan pembuatan KTP, Akta dan KK di Kabupaten Mesuji, dalam pengurusan administrasi kependudukan di Dinas Kependudukan dan Catatan Sipil Kabupaten Mesuji, masyarakat tentunya sangat mengharapkan adanya transparansi dari pemerintahan, baik 
transparansi mengenai tata cara atau prosedur dan proses dalam pembuatan KTP, Akta dan KK dalam pelayanan yang diberikan oleh Dinas Kependudukan dan Catatan Sipil.

Berdasarkan hasil wawancara peneliti dengan Kepala Bidang Pendaftaran Penduduk Terkait proses penyelenggaraan sudah transparan, tetapi tidak semua sudah transparan, karena data-data yang masyarakat miliki itu privasi tidak dapat untuk dipublikasikan, juga masyarakat dapat mengetahui informasi dari website resmi Dinas Kependudukan dan Catatan Sipil Kabupaten Mesuji. Hal ini pada Dinas Kependudukan dan Catatan Sipil Kabupaten Mesuji sudah menerapkan keterbukaan dalam melayani masyarakat dengan adanya website yang dapat membantu masyarakat mengetahui persyaratan maupun alur pelayanan dalam pembuatan KTP, Akta dan KK dan data pribadi yang dimiliki dapat tersimpan dengan rapih tanpa harus dipublikasikan dan dijamin kerahasiannya, namun dari masyarakat Kabupaten Mesuji masih belum memahami dan mengetahui proses penyelenggaraan atau alur pelayanan. Sehingga Dinas Kependudukan dan Catatan Sipil berperan penting untuk memberikan keterbukaan terhadap proses penyelenggaraan pelayanan maupun hal lainnya yang berhubungan dengan pelayanan yang diberikan Dinas Kependudukan dan Catatan Sipil Kabupaten Mesuji.

\subsection{Akuntabilitas Pelayanan Pembuatan KTP, Akta dan KK Pada Dinas Kependudukan dan Catatan Sipil Kabupaten Mesuji.}

Kinerja pelayanan publik dalam pelayanan pembuatan KTP, Akta dan KK adalah kewajiban petugas yang menangani pembuatan KTP, Akta dan KK salah satunya untuk meningkatkan kualitas pelayanan dalam pemberian layanan kepada masyarakat. Kinerja pegawai Dinas Kependudukan dan Catatan Sipil yang menangani pembuatan KTP, Akta dan KK dinilai baik, apabila seluruhnya atau sebagai besar pelayanan didasarkan untuk memenuhi harapan masyarakat sesuai dengan ketentuan yang telah ditetapkan. Akuntabilitas yang dilakukan pegawai yang menangani pembuatan KTP, Akta dan KK untuk memberikan pertanggung jawaban atas kinerja pelayanan dan tindakan yang diberikan kepada masyarakat.

Akuntabilitas sangat terkait dengan kinerja pelayanan, kinerja menciptakan pertimbangan dalam membuat kebijakan dan program. Sistem akuntabilitas kinerja menyediakan kerangka kerja yang mengukur hasil dan mengorganisasikan informasi digunakan secara efektif. Akuntabilitas menunjukkan ketaatan petugas pegawai yang menangani pembuatan KTP, Akta dan KK kepada peraturan, prosedur, yang berlaku, kemampuan untuk mengevaluasi kinerja, keterbukaan dan pembuatan keputusan, mengacu pada jadwal yang telah ditetapkan sesuai 
dengan standar operasinal pelayanan dan menerapkan efesien dan efektivitas terhadap pelayanan.

Pelayanan pembuatan KTP, Akta dan KK mempertanggungjawabkan kinerja para petugasnya secara transparan dan penting untuk dilaksanakan.Peneliti mewawacaai Kepala Bidang Pendaftaran Penduduk bahwa pedomam pokok pelaksanaan akuntabilitas pelayanan pembuatan KTP, Akta dan KK dengan menetapkan rincian tugas dan tanggung jawabn masing-masing para petugas yang membuat KTP, Akta dan KK sesuai dengan bidangnya. Semua pegawai yang bertugas menangani KTP, Akta dan KK sudah mempunyai kompetensi sesuai dengan tugas dan tanggung jawabnya, dan perannya dalam pelaksanaan pemberian layanan kepada masyarakat, hal ini dalam tingkat kelelahan mata mengakibatkan kesalahan dalam data tetapi kesalahan itu tidak selalu terjadi pada pegawai melainkan kesalahan dari masyarakat itu sendiri dalam pengisian data.

Peneliti menilai bahwa keyakinan kepada bidang pendaftaran penduduk di Dinas Kependudukan dan Catatan Sipil Kabupaten Mesuji yang meyakini bahwa kinerja pegawai yang menangani pembuatan KTP, Akta dan KK ini sudah sesuai. Hasil wawancara peneliti dengan staf bidang pengelolaan adminitrasi kependudukan bahwa dalam permasalahan kinerja dapat terukur dengan baik, pegawai sudah seoptimal mungkin untuk melayani apa yang dibutuhkan oleh masyarakat. Ketelitian dan prefesionalitas dalam bekerja menjadi hal yang uatama bagi pegawai untuk memberikan kepuasan terhadap masyarakat yang dilayani.

\section{PENUTUP}

\section{Kesimpulan}

1. Penerapan prinsip akuntabilitas dalam pelayanan KTP, AKTA, dan KK di Dinas Kependudukan dan Catatan Sipil Kabupaten Mesuji Kecamatan Raya sudah berjalan dengan baik. Hal tersebut tercermin dari jawaban dalam wawancara penelitian baik kepada Dinas Kependudukan dan Catatan Sipil Kabupaten Mesuji atau masyarakat yang mengatakan baik terhadap beberapa indikator yang terkandung di dalam prinsip akuntabilitas.

2. Transparansi dalam pelayanan pengurusan KTP, AKTA, dan KK di Dinas Kependudukan dan Catatan Sipil Kabupaten Mesuji terbukti terlaksana dengan baik. Hal tersebut tercermin dari jawaban dalam wawancara penelitian baik kepada Dinas Kependudukan dan Catatan Sipil Kabupaten Mesuji atau masyarakat tentang keterbukaan dalam Pelayanan kepengurusan KTP, AKTA, dan KK.

\section{Saran}

1. Mengingat Dinas Kependudukan dan Catatan Sipil Kabupaten Mesuji merupakan tingkatan yang paling tinggi dalam susunan pemerintahan Kabupaten, Mengingat Dinas Kependudukan dan Catatan Sipil 
Kabupaten Mesuji merupakan tingkatan yang paling tinggi dalam susunan pemerintahan Kabupaten, ditambah lagi dengan pelayanan publik yang berlangsung didalamnya masih bersifat sederhana, maka diharapkan agar segenap pegawai memberikan pelayanan yang maksimal kepada masyarakat. Sikap responsif, teliti, disiplin, dan ramah, merupakan salah satu perwujudan pelayanan yang maksimal. Pegawai Dinas Kependudukan dan Catatan Sipil Kabupaten Mesuji telah menerapkan hal yang demikian. Maka, hendaknya hal tersebut dapat dipertahankan dan kalau bisa ditingkatkan.

2. Peningkatan kualitas pelayanan publik juga dapat dilakukan oleh Kepala Dinas Kependudukan dan Catatan Sipil Kabupaten Mesuji dengan memberikan motivasi yang baik kepada pegawai Dinas Kependudukan dan Catatan Sipil Kabupaten Mesuji Pemberian penghargaan ( reward) kepada pegawai yang mampu menunjukkan prestasi yang baik.

\section{DAFTAR BUKU}

Keban, Yeremias T., 2008 Enam Dimensi Administrasi Publik, Konsep Teori dan Isu, Gava Media, Yogyakarta

Moenir, H.A.S. (2009). Manajemen Pelayanan Umum di Indonesia. Bandung: Bumi Aksara

Nurcholis, Hanif. 2010. Teori dan Pratik Pemerintahan dan Otonomi Daerah. Grasindo: Jakarta
Siagian, Sondang, 2010. Administrasi Pembangunan Konsep, Dimensi, dan Strategi. Jakrta:

Bastian, Indra, (2010). Akuntansi Sektor Publik.Suatu Pengantar. Jakarta: Penerbit Erlangga

Sinambela, Lijan Poltak, dkk.2010. Reformasi Pelayanan Publik. Jakarta : Bumi Aksara

Sinambela, Lijan Poltak, dkk.2008. Reformasi Pelayanan Publik. Jakarta : Bumi Aksara

Bungin, Burhan. 2011. Penelitian Kualitatif. Jakarta: Kencana Prenada Media Group.

Creswell, John Well. 2012. Research

Design (Pendekatan Kualitatif, Kuantitatif, dan Mixed). Yogyakarta: Pustaka Pelajar

Hamidi. 2010. Metode penelitian kualitatif. Malang: UMM Press

Hardiyansyah. 2011. Kualitas Pelayanan Publik. Yogyakarta: Gava Media.

Herdiansyah. 2010. Metodologi Penelitian Kualitatif. Jakarta: Salemba Humanika.

Keputusan Menteri Pendayagunaan Aparatur Negara No. 63/KEP/M.PAN/7/2003 Tentang Pedoman Umum Penyelenggaraan Pelayanan Publik

Keputusan Menteri Pendayagunaan Aparatur Negara No. 26/KEP/M.PAN/2/2004 Tentang Petunjuk Teknis Transparansi 
dan Akuntabilitas Dalam

Penyelenggaraan Pelayanan Publik

Undang-undang No. 24 Tahun 2013 tentang Administrasi Kependudukan.

Undang-undang Nomor 25 Tahun 2009 tentang Pelayanan Publik.

Peraturan Pemerintah Republik Indonesia Nomor 37 tahun 2007 tentang Pelaksanaan Undangundang Nomor 23 Tahun 2006 Tentang Administrasi Kependudukan

Peraturan Presiden Republik Indonesia Nomor 25 Tahun 2008 tentang Persyaratan dan Tata Cara Pendaftaran Penduduk dan Pencatatan Sipil

Perpres No. 26 Tahun 2009 tentang Penerapan KTP Berbasis NIK Secara Nasional

Perpres No. 35 Tahun 2010 Tentang Perubahan atas Perpres No. 26 Tahun 2009 tentang Penerapan KTP Berbasis NIK Secara Nasional

Kepres No. 10 Tahun 2010 tentang Tim Pengarah; Permendagri No. 6 Tahun 2011 tentang Spesifikasi Perangkat Keras, Lunak, Blanko KTP Elektronik

Permendagri No. 9 Tahun 2011 tentang Pedoman Penerapan KTP Berbasis NIK Secara Nasional.

Peraturan Bupati Mesuji Nomor 37 tahun 2012 tentang organisasi dan tata kerja perangkat Daerah Kabupaten Mesuji 